\title{
The Implementation of Senior High School Work Immersion Program in Selected Public Schools in Negros Occidental
}

\author{
Corazon T. Vecino ${ }^{1}$ and Araceli C. Doromal ${ }^{2}$ \\ ${ }^{1}$ Victorias National High School, Victorias City, Philippines \\ ${ }^{2}$ University of Negros Occidental-Recoletos, Bacolod City, Philippines
}

\begin{tabular}{l} 
Article history \\
Submitted: 4 July 2020 \\
Revised: 1 November 2020 \\
Accepted: 12 November 2020 \\
\hline Keywords: \\
Education \\
Management \\
Work Immersion Program \\
Public Senior High School \\
Descriptive-Comparative \\
Negros Occidental
\end{tabular}

Implementation and Compliance, Work Immersion Delivery Process, Assessment of Student's Progress, Supervision of Work Immersion and Implementation, and Administrative Concerns. Likewise, it identifies the challenges encountered by the implementers and their recommendations in the effective implementation of the immersion program.

Methods. A descriptive-comparative research design was used to assess the extent of implementation of senior high school work immersion program in selected public schools in the Division of Negros Occidental during the school year 2019-2020. Using stratified random sampling, 204 implementers participated in the study. A checklist and an open-ended questionnaire were developed based on the Department of Education work immersion guidelines on monitoring and evaluation tools (DepEd, 2017) for data gathering. Mean, Standard Deviation, Kruskal-Wallis, Mann Whitney, frequency count, percentage distribution, and ranking method were used in the data analysis.

Results. The findings of the study revealed that the extent of implementation of senior high school work immersion program in selected public schools in the Division of Negros Occidental was evident or fully implemented as a whole and according to the category of school, school location, and designation of the implementer. Specifically, no significant difference in its extent of implementation in terms of the category of school, school location, and designation of the implementer. The findings also revealed that the most encountered challenges in the immersion implementation were limited partner industries, students' working attitude, limited time tracking student's progress, inadequate supervision time for immersion teachers, and not sustainable learners' financial support. Furthermore, the major recommendations on effective immersion implementation were to tap additional partner institutions, increase immersion hours, weekly conference reporting of student's progress, and enough supervision and monitoring time for immersion teachers and allocate immersion budget.

Conclusion. Implementers have major responsibilities in establishing a process that turns policies into actions critical in carrying out the work immersion guidelines by providing proof of implementation evidence. Therefore, it implies that they are the key persons that ensure the delivery of the immersion program despite the challenges encountered. Likewise, they are also responsible for establishing the authenticity of documents that need further rigid onsite validation by the internal and external stakeholders in the school and division levels. In conclusion, the immersion program was implemented based on the document pieces of evidence.

Practical Value of the Paper. The study contributes significantly to the limited literature on the extent of the work immersion implementation in public senior high schools. Additionally, the findings of the study provided baseline information to the school personnel in designing a proposed 
enhanced management system on the senior high school immersion program to ensure the extent of its implementation and address its challenges and recommendations.

\section{References}

Abella, R. (2019). A Close look at the needs and challenges faced by the senior high school students of the accountancy, business, and management strand. International Journal of Advanced Research, (7)2, 744-751. https://doi.org/10.21474/IJARO1/8541.

Bustamante, J. (2019). Senior high school work immersion pioneers: A phenomenological study. Journal of International Academic Research for Multidisciplinary, (7)2, https://www.jiarm.com/article.

Dela Cruz, G., Dela Cruz, M. Paez, S., Panahon, J., \& Pascual, M. (2019). An assessment of knowledge, skills, and attitudes of accountancy, business, and management (ABM) students of senior high schools in Cabanatuan. International Journal of Advanced Engineering, Management, and Science, (5)6. https://doi.org/10.22161.

Department of Education (2017). DepEd Order No. 30, s. 2017, Guidelines for work immersion. https://www.dedped. gov.ph.

Estonanto, A. J.J. (2017). Acceptability and difficulty of the STEM track implementation in senior high school. Asia Pacific Journal of Multidisciplinary Research, 5(2), 43-50. https://www.apjmr.com/wp-content/uploads/2017/04/ APJMR-2017.5.2.05.pdf.

Felicen, S. \& Ylagan, A. (2018). The hospitality management curriculum of ASEAN member states. Asia Pacific Journal of Education, Arts, and Science. 5(2), 8-14. https://www.semanticsholar.org/article.

Li, J., Steele, J., Slater, R., Bacon, M., \& Miller, T. (2016). Teaching practices and language use in two-way language immersion programs in a large public school district. International Multilingual Research Journal, 10(1), 31-43. https://doi.org/10.1080/19313152.2016.1118669.

Molina, R. (2019). Development of an instrument to measure practical research competencies in Senior High School. International Journal of Educational Researchers, 10(4), 20-36. https://ijer.penpublishing.net/makale/1227.

Pamittan, R., Pascual, M., \& Prestoza, M. (2018). The performance level of skilled and non-skilled automotive students during work immersion. International Journal of Computer Science \& Communication, 3(1),1-10. https://doi.org/10.5281/2561506.

Subia, G. (2018). Think like my teacher (TLMT): A new method in assessing millennial learners. International Journal of Arts, Humanities, and Social Sciences, 3(1). https://www.ijahss.com/Paper/03012018/1079495510.pdf.

Tismal, A., Awais, M., \& Shoaib, O. (2016). On the job training and its effectiveness: An employee perspective. South Asian Journal of Banking and Social Sciences, 2(1),22. https://www.researchgate.net.publicaion/305699923.

\section{Correspondence:}

Corazon T. Vecino [Corazon.vecino@yahoo.com]

https://orcid.org/0000-0003-2262-0529 